\title{
Who owns a dead man's sperm?
}

\section{Cannold}

\author{
A sad outcome, but the right one
}

$\mathrm{T}$ he Brisbane Supreme Court has denied an Australian woman's request to harvest and freeze her dead fiancé's sperm for future impregnation. After she was denied access to the sperm, the woman learnt that her fiancé may have been a sperm donor and she began checking to find out if his sperm was still available. Given what we know, there is a good ethical argument that the woman should not have access to the sperm and have her dead fiance's child. Another aspect of this case is that it illustrates the way in which ethics, law, and personal opinion can differ.

It used to be that when men died, their chance of generating new life went with them. But this is no longer the case. Simone Baker, the woman at the centre of the recent Brisbane Supreme Court Decision, is just one of a growing number of individuals-not just wives, but girlfriends, parents, and even in one case a social worker ${ }^{1}$-who have sought over the last few decades to obtain legal permission to extract, store, and use the sperm of dead men to achieve a pregnancy.

My experience as a bioethicist is that my emotional and rational responses to cases usually coincide. However, in cases like Baker's, I tend to find myself sympathising with the loved ones who seek a dead man's sperm and automatically trusting their motives for doing so. However, on considered reflection, I believe the cases of sperm seekers are invariably weak. In my view, a legitimate decision to grant a sperm seeker access to a dead man's sperm needs to be grounded in a belief that the seeker's access and use of the sperm would not contravene the dead man's autonomy but-through doing what "he would have wanted"-extend it. Such a decision would also need to be based on a clear conviction that in attempting to gain access to the dead man's sperm, the seeker is not using the dead man as a means to their own ends, but both expressing her love for him and attempting, by enabling the birth of his genetic offspring, to pay tribute to him.

If the decision maker does not believe these two things, I believe it would be unjustified for her to grant the seeker access to the dead man's sperm. This is because, in doing so, she would be overriding two important-if not foundational-principles of medical ethics: the prohibition on violating a corpse (or the body of a brain dead person) for reasons other than their own benefit, and the requirement that informed consent be obtained from a person prior to a procedure being undertaken.

Upon reflection, I believe that sperm seekers should not automatically be trusted to be seeking sperm for the right reasons-a desire to extend the dead man's autonomy and not as a means to their own ends-but that they should have to prove that their reasons are right. Because of the circumstances surrounding such cases, I believe it would nearly always be difficult for them to do. This is firstly because when most sperm seekers are making their decisions about (and their case for) the extraction, storage, and/or use of the dead man's sperm, they are in the early stages of grief (there is a window of opportunity of about seven days after the body expires for viable sperm to be extracted). Such grief may make it difficult for the seeker to be clear in their own mind about the precise nature of their motive for seeking the sperm and the existence and/or quality of the evidence to support a contention that recovering the sperm would be what the dead man would have wanted. This lack of clarity would make it difficult for them to persuade others that their reasons for wanting the sperm are sound.

However, this may only be an argument against allowing sperm seekers early use of collected sperm to pursue a child, rather than an argument against their being allowed to collect it now for possible use later. However, when a life partner or son dies, grief typically lasts for many years and part of what is mourned is the loss of the life one expected and wanted to have with the deceased. In the face of such a loss, the bereaved may seek to recover as many aspects of the life they expected and thought they would have-in the case of sperm seekers, one with children in itas they can. Although this is completely understandable, it might be expected to influence the objectivity of the answer the sperm seeker gives to the central question that will and must be answered: in this situation, what would the dead man have wanted?
Typically, sperm seekers claim that their gaining access to the sperm would be what the dead man wanted on the grounds that he had wanted and intended to become a father, and may even have acted in pursuit of this intention. Simone Baker claimed that her fiancé Andrew would have wanted her to have his sperm because the two had intended to have children together and had even decorated a nursery and picked out babies' names. However, to state the often overlooked obvious, it is significantly different for a man to intend to consent to use his sperm to create a child while he is alive and intending to remain that way, than to consent to have his sperm extracted from his dead body, stored, and later used to create a pregnancy. This is not to say that Andrew or any of the other dead men at the centre of such cases necessarily wouldn't have given such consent, but rather that their intended consent, when alive, to becoming a father tells us little about what their views would be on posthumous use of their sperm.

So although I sincerely sympathise with the plight of Simone Baker and sperm seekers like her, I must conclude that the Brisbane Supreme Court's decision to deny her access to her dead finance's sperm was the right one. The only ethical way for sperm seekers in the future to avoid finding themselves in Baker's situation is to discuss with their alive and competent partners or sons now-just as they might discuss organ donation or the terms of a living will-what they would want to happen to their sperm should the unthinkable come to pass.

$J$ Med Ethics 2004;30:386.

doi: 10.1136/jme.2003.004853

Correspondence to: Dr L Cannold, Centre for Applied Philosophy and Public Ethics, University of Melbourne, 3010 Australia; LCannold@unimelb.edu.au

Received 23 June 2003

Accepted for publication 5 August 2003

\section{REFERENCE}

1 McLean SA. Post-mortem human reproduction: legal and other regulatory issues. J Law Med 2002;9:429-37. 